\title{
ЗАСТОСУВАННЯ ВЕКТОРА ЦИКЛІЧНИХ РИТМІЧНО ПОВ'ЯЗАНИХ ВИПАДКОВИХ ПРОЦЕСІВ ДЛЯ НЕІНВАЗИВНОЇ ЕЛЕКТРОКАРДІОГРАФІЇ ПЛОДА
}

\author{
ДВНЗ «Тернопільський державний медичний університет \\ імені І. Я. Горбачевського МОЗ України»

\section{METHODS FOR ANALYSIS OF THE SYNC REGISTERED BIOSIGNALS \\ N. O. Kravets} \\ SHEI «Ternopil State Medical University by I. Ya. Horbachevsky of MPH of Ukraine»
}

Н. О. Кравець

Вступ. Отримання діагностичної інформації про стан серцево-судинної системи дитини, яка знаходиться в утробі матері, обгрунтовує необхідність використання методів неінвазивної електрокардіографії плода. Здійснення такого високоінформативного моніторингу $є$ собою комплексною проблемою, теоретично і практично взаємопов'язаною на рівні адаптаційно-пристосувальних реакцій у рамках єдиної системи «мати-плацента-плід».

Результати та їх обговорення. Для дослідження пропонується використовувати електрокардіосигнали плода і матері, які синхронно зареєстровані сучасним портативним електрокардіографом БЕБІКард (виробництва XАI МЕДІКА).

Більшість існуючих методів обробки електрокардіосигналів плода і матері грунтуються на математичних моделях у вигляді вектора випадкових величин, стохастичного періодичного процесу, вектора періодичних, із різними періодами, випадкових процесів. Однак у даних математичних моделях не враховуються важливі властивості досліджуваних біосигналів - мінливість та спільність їх ритму. У роботах ряду авторів показана ефективність застосування методів сумісної обробки синхронно зареєстрованих кардіосигналів на основі моделі вектора циклічних ритмічно пов'язаних випадкових процесів.
Аналізуючи електрокардіосигнали плода і матері, що реєструються сучасними кардіодіагностичними системами, враховуючи факт подібності їх просторово-часових структур та генезису, в якості математичної моделі досліджуваних біосигналів доцільно використати модель вектора циклічних ритмічно пов'язаних випадкових процесів. Запропонована математична модель повинна описуватися сукупністю сумісних імовірнісних характеристик, зокрема сумісних функцій розподілу, взаємних змішаних моментних функцій, взаємокореляційних функцій, а також повинна враховувати спільність ритмічної структури досліджуваних сигналів.

Висновок. При такому уніфікованому підході до моделювання та аналізу електрокардіосигналів плода і матері відкривається можливість сумісного (паралельного) аналізу декількох циклічних біосигналів, що може суттєво підвищити точність, достовірність та повноту обстеження.

У цьому контексті актуальним $\epsilon$ проведення подальших наукових досліджень на предмет обгрунтування, верифікації та застосування вектора циклічних ритмічно пов'язаних випадкових процесів як математичної моделі електрокардіосигналів плода і матері з метою їх сумісної обробки та імітації в сучасних комп'ютерних кардіодіагностичних системах. 